\title{
The effect of new probiotic strain Lactobacillus plantarum on counts of coliforms, lactobacilli and bacterial enzyme activities in rats exposed to $\mathbf{N}, \mathbf{N}$-dimethylhydrazine (chemical carcinogen)
}

\author{
Denisa Čokášová1, Alojz Bomba ${ }^{1}$, Ladislav Strojný ${ }^{1}$, Beata Pramuková1, \\ Viktória Szabadosová ${ }^{,}$, Rastislav Salaj ${ }^{1}$, Jana Žofčáková1, Andrea Brandeburová1, \\ Anna Supuková ${ }^{1}$, Alena Šoltésová ${ }^{1}$, Emília Hijová $^{1}$, Júlia Ričanyová1, \\ Leonard Siegfried $^{2}$, Peter Supuka ${ }^{3}$
}

${ }^{1}$ Institute of Experimental Medicine, Faculty of Medicine, ${ }^{2}$ Institute of Medical and Clinical Microbiology, P. J. Šafárik University, Košice, Slovak Republic

${ }^{3}$ Institute of Animal Husbandry, University of Veterinary Medicine and Pharmacy, Košice, Slovak Republic

\section{Received September 23, 2011 \\ Accepted April 11, 2012}

\begin{abstract}
The aim of the present study was to evaluate the effect of the new probiotic strain Lactobacillus plantarum on chemically induced carcinogenesis in rats. Sprague dowley rats $(\mathrm{n}=33)$ were divided into control and experimental groups and were fed a conventional laboratory diet. In the experimental group, rats were treated with the probiotic at the dose of $1 \times 10^{9} \mathrm{CFU}$ (colonyforming units) $/ \mathrm{ml}$. Two weeks after the beginning of the trial, N,N-dimethylhydrazine (chemical carcinogen) injections were applied s.c. at the dose of $21 \mathrm{mg} / \mathrm{kg}$ b.w., $5 \times$ weekly. At the end of the 8-month experimental period, faeces samples were taken from the rats and used for laboratory analysis. The counts of lactobacilli and coliforms and bacterial enzyme activity were determined. The probiotic strain L. plantarum as single species or in combination with oil (Lini oleum virginale) decreased the count of total coliforms and increased lactobacilli in faeces of rats. Application of probiotic microorganisms significantly $(P<0.05)$ decreased the activities of bacterial enzymes ( $\beta$-galactosidase and $\beta$-glucuronidase) compared to the control group rats. The results of this study indicate that probiotic microorganisms could exert a preventive effect on colon carcinogenesis induced by N,N-dimethylhydrazine.
\end{abstract}

Colon cancer, prevention, faeces, Sprague dowley

Colon cancer is one of the most common forms of malignant tumours in humans, and its incidence is increasing. Cancer mortality will continue to rise with an estimated 9 milion people dying from cancer in 2015, and 11.4 milion dying in 2030 according to World Health Statistics (2008). Diet makes an important contribution to colon cancer risk, which implies the risks of colon cancer are potentially reducible (Rafter 2004). Lactic acid bacteria probiotics are viable microbial food ingredients supposed to be beneficial through their effect on the intestinal tract. The majority of the probiotics used today belong to the Lactobacillus group (Jenkins et al. 2005). New probiotic strains with antimicrobial effects can be isolated from plants and animals (Marciňáková et al. 2008; Herich et al. 2010). Some studies showed that a high fat diet increased the risk of colon cancer (Meyerhardt et al. 2007). 1,-2-dimethylhydrazine is a common colon carcinogen often used in developing colorectal cancer in various experimental animals (Fukui et al. 2001; Lunz et al. 2008). Lactic acid bacteria or a soluble compound produced by the bacteria may interact directly with tumour cells in culture and inhibit their growth. Kumar et al. (2009) observed that the oral administration of lactic acid bacteria Lactobacillus acidophilus and Lactobacillus casei and curd culture of Lactococcus lactis biovar diacetylactis DRC-1 in milk effectively reduced DNA damage induced by chemical carcinogens (1,2-dimethylhydrazine) in the colonic mucosa of rats in a trial of 40 weeks. 
The aim of this study was to evaluate the effects of the new probiotic strain Lactobacillus plantarum on counts of coliforms, lactobacilli and bacterial enzyme activities in rats exposed to N,N-dimethylhydrazine.

\section{Materials and Methods}

Animals and feeding

Rats $(\mathrm{n}=33$, mixed sex) of 6 months of age were used in the study. The rats (Sprague dowley) were reared in the Central Vivarium, Medical Faculty, P. J. Šafárik University, Košice, Slovak Republik. They were housed in plastic cages at controlled climate (temperature of $22{ }^{\circ} \mathrm{C}$ ) favourable for their growth and welfare. The experiment was performed complying with the ethical requirements for animal handling pursuant to Acts No. 289/2003 and 489/2003 of the Slovak Republic. The experiment was approved by the Ethics Committee. The animals were fed a conventional diet for 8 months of the experiment, manufactured by Biofer (Slovak Republic). Lini oleum virginale (Dr. Kulich Pharma, Czech Republic) at a dose of 4\% was obtained from Linum usitatissimum flaxseed containing high concentrations of polyunsaturated fatty acids. Feed and water were provided ad libitum. At the end of the 8 months the rats were anaesthetized by ketamine $100 \mathrm{mg} / \mathrm{kg}+$ xylazine $15 \mathrm{mg} / \mathrm{kg}$ b.w., i.p. and the fresh samples of faeces were taken from the intestine part of the caecum in all experimental rats after death. During the study there was a death of three animales (males), one rat in group 3 and two rats in group 4.

\section{Microbiological assays}

Various strains of lactobacilli were isolated from rectal human swabs. The obtained solution (100 $\mu 1$ of each) was spread-plated onto Lactobacillus selective agar (LS agar) (IMUNA-Pharm, Slovak Republic). The isolated lactobacilli strains were randomly selected and Gram stained and visualised under microscope for morphological characterisation. The gram-positive and catalase-negative strains were tested for the ability to prove inhibited zones against the pathogen E. coli (CNCTC Eck 63/59, Czechoslovak Collection of Microorganisms) by the agar diffusion test. The most suitable strain was characterised as Lactobacillus plantarum using the molecular genetic method of polymerase chain reaction (PCR) according to Berthier and Ehrlich (1998). The characterised L. plantarum $\left(1 \times 10^{9} / \mathrm{ml}\right)$ was aerobically prepared at $37{ }^{\circ} \mathrm{C}$. Firstly, $4 \mathrm{ml}$ of the cultures were mixed with $36 \mathrm{ml}$ of skimmed milk. The milk was then filled (at a temperature of $22-25^{\circ} \mathrm{C}$ ) into screw-capped bottles and administered daily to drink rats (groups 3,4 ).

\section{Experimental design}

The rats were randomly divided into 4 groups of $7-9$ rats each:

Group 1 - control group without any supplements,

Group 2 - control group without any supplements and chemically induced carcinogenesis with N,Ndimethylhydrazine,

Group 3 - chemically induced carcinogenesis with N,N-dimethylhydrazine + L. plantarum (probiotic) in milk,

Group 4 - chemically induced carcinogenesis with N,N-dimethylhydrazine + L. plantarum (probiotic) in milk $+4 \%$ oil (Lini oleum virginale) in feed.

Application of N,N-dimethylhydrazine

Experimental groups of rats (groups 2, 3 and 4) were treated with N,N-dimethylhydrazine (Merck, Germany) at a dose of $21 \mathrm{mg} / \mathrm{kg}$ s.c., twice a week, 2 weeks after the administration of diets. Group 1 of rats was not treated with N,N-dimethylhydrazine. After 8 months of the experiment the rats were anaesthetised i.p. by ketamine 100 $\mathrm{mg} / \mathrm{kg}$ and xylazine $15 \mathrm{mg} / \mathrm{kg}$ b.w.

Preparation of faecal samples

Fresh samples of faeces were taken from the intestinal part of the caecum in all experimental rats after death. Faeces of rats $(1 \mathrm{~g})$ were placed in sterile polyethylene Stomacher Lab Blender bags with sterile diluents $(9 \mathrm{ml})$ of saline and mixed in a Stomacher 400 Bag mixer (France). Series of 10-fold dilutions (from $10^{-2}$ to $10^{-8}$ ) were made in the same sterile diluents. The dilutions (100 $\mu 1$ of each) were spread-plated onto two selective agars MacConkey agar (Merck, Germany) for coliforms and Rogosa agar (Biocar Diagnostics, France) for lactobacilli. The plates for lactobacilli were put into box (Gas PaK, USA) and incubated at $37{ }^{\circ} \mathrm{C}$ for $48 \mathrm{~h}$. The plates for coliforms were incubated aerobically at $37^{\circ} \mathrm{C}$ for $24 \mathrm{~h}$. The colonies were counted and bacteria were Gramstained in a light microscope. The viable counts were expressed as the log 10 of colony-forming units (CFU/g) of faeces.

Evaluation of enzymatic activity of bacterial enzymes

Freshly collected samples of faeces were also used to evaluate the enzymatic activity of bacterial enzymes - galactosidase $(\alpha$-GAL), $\beta$-galactosidase $(\beta$-GAL), $\beta$-glucuronidase ( $\beta$-GLUCUR), $\alpha$-glucosidase $(\alpha$-GLU) and $\beta$-glucosidase $(\beta$-GLU) using an (SIGMA-ALDRICH, Bratislava). Bacterial enzymes activity in the caecal digesta is measured by the rate of release of $p$ - or $o$-nitrophenol from their nitrophenylglucosides according to the modified method of Djouzi and Andrieux (1997) described in details by Juśkiewicz et al. (2002). 
Histopathological evaluation of tumours

Biopsy samples of the caecum were fixed in $10 \%$ neutral formalin solution during $48-72 \mathrm{~h}$. The samples were drained and embedded in parafin blocks. Histological sections were stained by haematoxylin-eosin and determined microscopically.

Statistical analysis

Statistical analysis was performed by Student's $t$-test and analysis of variance (ANOVA) with significance $P$ $<0.05 ; P<0.01$ and $P<0.001$.

\section{Results}

Counts of lactobacilli and coliforms

As shown in Table 1, administration of the probiotic caused an increase in the counts of lactobacilli $\left(9.51 \pm 0.34 \times 10^{8} \mathrm{CFU} / \mathrm{g}\right)$ in group 3 compared to control group $2(8.86$ $\left.\pm 0.64 \times 10^{8} \mathrm{CFU} / \mathrm{g}\right)$. However, significant increase $(P<0.001)$ in counts of lactobacilli was observed after the administration of the combination of probiotic-oil in group 4 (10.25 $\pm 0.39 \times 10^{8} \mathrm{CFU} / \mathrm{g}$ ) compared to control group 2. When comparing groups 1 and 2 , no significant difference was observed. We recorded an increase in the counts of lactobacilli in probiotic and probiotic-oil groups of rats.

Table 1. Counts of lactobacilli and coliforms (CFU/g) administration of probiotic (Lactobacillus plantarum) and probiotic-oil to experimental rats

\begin{tabular}{llcl}
\hline Groups* & \multicolumn{1}{c}{ Supplement } & Lactobacilli & Coliforms \\
\hline 1 & & $8.99 \pm 0.45$ & $6.16 \pm 0.55$ \\
2 & N,N-dimethylhydrazine & $8.86 \pm 0.64$ & $6.34 \pm 0.24$ \\
3 & N,N-dimethylhydrazine+probiotic & $9.51 \pm 0.34^{* * *}$ & $5.14 \pm 0.48^{* * *}$ \\
4 & N,N-dimethylhydrazine+probiotic + oil & $10.25 \pm 0.39^{* * *}$ & $5.97 \pm 0.44^{* * *}$ \\
\hline
\end{tabular}

*Group 1 - control group without any supplements,

Group 2 - control group without any supplements, (chemically induced carcinogenesis) with $\mathrm{N}, \mathrm{N}$-dimethylhydrazine,

Group 3 - chemically induced carcinogenesis with N,N-dimethylhydrazine + L. plantarum (probiotic) in milk,

Group 4 - chemically induced carcinogenesis with N,N-dimethylhydrazine $+L$. plantarum (probiotic) in milk $+4 \%$ of oil (Lini oleum virginale) in feed

Data are expressed as mean $\pm \mathrm{SD}$

Significant differences calculated from group 2 are designated as $* * *(P<0.001)$

When comparing the coliforms in group 1 and group 2, no significant differences were observed. A significant $(P<0.001)$ decrease of coliforms $\left(5.97 \pm 0.44 \times 10^{4} \mathrm{CFU} / \mathrm{g}\right)$ was found after administration of probiotic-oil in group 4 (Table 1) compared to control group 2 $\left(4.67 \pm 1.03 \times 10^{4} \mathrm{CFU} / \mathrm{g}\right)$. Administration of probiotic in group $3\left(5.14 \pm 0.48 \times 10^{4} \mathrm{CFU} / \mathrm{g}\right)$ decreased the counts of coliforms compared to control group $2\left(6.34 \pm 0.24 \times 10^{4} \mathrm{CFU} / \mathrm{g}\right)$.

\section{Bacterial enzyme activity}

The results of the present study showed a decrease in the activities of bacterial enzymes after the addition of probiotic or probiotic-oil to the rats' diet (Table 2). Significant decreases in the activities of $\beta$-GAL and $\beta$-GLUCUR were observed after the addition of probiotic and probiotic-oil in groups 3 and 4 .

Our results confirmed the positive impact of lactobacilli on the presence of microorganisms in the intestinal ecosystem (lactobacilli and coliforms) resulting in decreased activity of $\beta$-glucuronidase and $\beta$-galactosidase.

Histopathological changes

Rats from control group 1 did not reveal any histopathological changes. The epithelium showed significant histological changes; epithelial cells produced sufficient deep crypts. 
Table 2. Changes in activity of bacterial enzymes in rats.

\begin{tabular}{llllll}
\hline Groups* & $\alpha$-GAL & $\beta$-GAL & $\beta$-GLUCUR & $\alpha$-GLU & $\beta$-GLU \\
\hline 1 & $0.21 \pm 0.06$ & $0.06 \pm 0.02$ & $0.28 \pm 0.10$ & $0.08 \pm 0.04$ & $0.08 \pm 0.02^{* * *}$ \\
2 & $0.11 \pm 0.06^{* *}$ & $0.07 \pm 0.04$ & $0.37 \pm 0.15$ & $0.15 \pm 0.05^{* *}$ & $0.04 \pm 0.01^{* * *}$ \\
3 & $0.32 \pm 0.15^{* *}$ & $0.03 \pm 0.01^{*}$ & $0.17 \pm 0.05^{* *}$ & $0.18 \pm 0.04$ & $0.15 \pm 0.02^{* * *}$ \\
4 & $0.29 \pm 0.13^{* *}$ & $0.06 \pm 0.02$ & $0.3 \pm 0.14$ & $0.12 \pm 0.08$ & $0.06 \pm 0.01 *$ \\
\hline
\end{tabular}

*Group 1 - control group without any supplements,

Group 2 - control group without any supplements, (chemically induced carcinogenesis) with N, N-dimethylhydrazine,

Group 3 - chemically induced carcinogenesis with N,N-dimethylhydrazine $+L$. plantarum (probiotic) in milk, Group 4 - chemically induced carcinogenesis with $\mathrm{N}, \mathrm{N}$-dimethylhydrazine $+L$. plantarum (probiotic) in milk + $4 \%$ of oil (Lini oleum virginale), in feed

$\alpha$-GAL ( $\alpha$-galactosidase), $\beta$-GAL ( $\beta$-galactosidase), $\beta$-GLUCUR ( $\beta$-glucuronidase), $\alpha$-GLU ( $\alpha$-glucosidase), $\beta$-GLU ( $\beta$-glucosidase)

Data are expressed as means $\pm \mathrm{SD}$, significant differences calculated from group 1 are designated as: $* P<0.05$; $* * P<0.01 ; * * * P<0.001$

In control group 2 histological changes showed enlarged lymph follicles that were brought to the surface of damaged epithelial lining of the tunica mucosa layer. A cluster of morphologically altered cells showing neoplastic changes was found in the layer of tunica mucosa. Histopathological changes showed an ongoing long-term chronic inflammatory process of the lining of the colon induced by experimental application of the chemical N,N dimethylhydrazine.

\section{Discussion}

The effect of probiotics on prevention of colorectal cancer confirms the importance of bacterial flora in the aetiology of colorectal cancer and at the same time represents an appropriate way of decreasing its incidence.

The influence of probiotics and prebiotics was also described in animals. Nemcová et al. (1999) found after administration of the strain Lactobacillus paracasei as single species or L. paracasei in combination with fructooligosaccharides (Raftilose P95) to experimental piglets that compared to control groups, the counts of coliforms were significantly decreased by $1 \log$ in probiotic and probiotic-prebiotic groups.

Le Blanc (2005) evaluated the role of yoghurt starter bacteria and their cellfree fermentation products in the reduction of procarcinogenic enzyme activities ( $\beta$-glucuronidase and nitroreductase). Mice injected with 1,2 dimethylhydrazine and fed yoghurt were used in their study. Feeding yoghurt decreased procarcinogenic enzyme levels in the large intestine contents of mice bearing colon tumour.

$\beta$-Glucuronidase is an enzyme responsible for the hydrolysis of glucuronides in the lumen of the gut. This reaction generates toxic and carcinogenic substances which are detoxified by glucuronidase formation in the liver and then enter the bowel via bile. In this way, toxic aglycones can be regenerated in situ in the bowel by bacterial $\beta$-glucuronidase. In humans, the faecal $\beta$-glucuronidase activity was shown to be higher in colorectal cancer patients compared to healthy controls suggesting a role of this enzyme in carcinogenesis (Kim and Jin 2001). Studies in humans have demonstrated that the capacity of probiotics to decrease the activity of bacterial enzymes is strain specific (Goossens et al. 2003).

Based on an experimental study, Bertková et al. (2010) suggested that Hippocastani extractum siccum may be a useful candidate agent for colon cancer chemoprevention and treatment. They investigated the effect of probiotic microorganisms and selected bioactive compounds in different combinations on decreasing the concentration of 
bile acids in blood serum activity of bacterial enzymes in colon contents, short-chain fatty acids, IL-6 levels and increased TNF- $\alpha$ - level in comparison with their individual application. The results of their experiment indicate that probiotic microorganisms and bioactive compounds could exert a preventive effect on colon carcinogenesis induced by dimethylhydrazine.

Although the administration of probiotic with oil, specifically with Lini oleum virginale, to rats was not documented, the effect of fish oil ingestion on colonic carcinogenesis in rats was studied by Moreira et al. (2009). The results obtained from our study indicate a positive effect of administering the combination of the strain L. plantarum as probiotic with oil. Changes in counts of coliforms and lactobacilli reflected the activities of bacterial enzymes. Our study shows the possibility of using either a probiotic strain (L. plantarum) as single species or in combination with oil (Lini oleum virginale) for decreasing the count of total coliforms and increasing lactobacilli. It can be used not only in the treatment of animals, but also mainly in the prevention of colorectal carcinoma in humans. Optimal dietary manipulation could be a good alternative in preventing many, mainly carcinoma diseases, not only in animals but also in humans.

\section{Acknowledgements}

This work was partially supported by the Agency of the Slovak Ministry of Education for the Structural Funds of the EU, under the project ITMS: $2622020104(60 \%)$ and by the project of the Scientific Grant Agency of the Minictry of Education of Slovak Republic and the Academy of Sciences VEGA 1/0372/10 "Modulation of the gastrointestinal ecosystem and metabolic status using probiotic microorganisms and bioactive substances in the chronic diseases prevention" (40\%) and VEGA 1/0751/12.

\section{References}

Berthier F, Ehrlich SD: Rapid species identification within two groups of closely related lactobacilli using PCR primers that target the $16 \mathrm{~S} / 23 \mathrm{~S}$ rNA spacer region. Microb Letters 161: 97-106

Bertková I, Hijová E, Chmelárová A, Mojžišová G, Petrášová D, Strojný L, Bomba A, Žitňan R 2010: The effect of probiotic microorganisms and bioactive compounds on chemically induced carcinogenesis in rats. Neoplasma 57: 422-428

Djouzi Z, Andrieux C 1997: Compared effect of the three oligosaccharides on metabolism of intestinal microflora on rats inoculated with a human faecal flora. Br J Nutr 78: 313-324

Fukui M, Fujino T, Tsutsui K, Maruyama T, Yoshimura H, Shinohara T, Fukui M, Nada O 2001: The tumourpreventing effect of a mixture of several lactic acid bacteria on 1,2-dimethylhydrazine-induced colon carcinogenesis in mice. Onc Report 8: 1073-1078

Herich R, Kokinčáková T, Lauková A, Levkutová M 2010: Effect of preventive application of Enterococcus faecium EF55 on intestinal mucosa during salmonellosis in chickens. Cz J An Sci 55: 42-47

Jenkins B, Holsten S, Bengmark S, Martindale R 2005: Probiotics: A practical review of their role in specific clinical scenarios. Nut Clin Prac 20: 262-270

Juśkiewcz J, Zduńczyk Z, Wróblewska M, Oszmiański J, Hernandez T 2002: The response of rats to feeding with diets containing grapefruit flavonoid extract. Food Res Int 35: 201-205

Kumar A, Kumar NS, Phushpalata RS 2009: Inhibition of 1,2-dimethylhydrazine induced colon genotoxicity in rats by the administration of probiotics curd. Mol Bio Rep 10: 1-4

Le Blanc AM, Perdigón G 2005: Reduction of beta-glucuronidase and nitro-reductase activity by yoghurt in a murine colon cancer model. Biocell Mendoza 29: 1-17

Lunz W, Peluzio MCG, Dias CMGC, Moreira APB, Natali AJ 2008: Long-term aerobic swimming training by rats reduces the number of aberrant crypt foci in 1,2-dimethylhydrazine-induced colon cancer. Braz J Med Bio Res 41: 1000-1004

Marciňáková M, Lauková A, Simonová M, Strompfová V, Koréneková B, Nad' P 2008: A new probiotic and bacteriocin-producing strain of Enterococcus faecium EF 9296 and its use in grass enciling. Cz J An Sci 53: 336-345

Meyerhardt JA, Niedzwiecki D, Hollis D, Saltz LB, Hu FB, Mayer RJ, Nelson H, Whittom R, Hantel A, Thomas J, Fuchs CS 2007: Association of dietary patterns with cancer recurrence and survival in patients with stage III colon cancer. J Am Med Ass 298: 754-764

Moreira APB, Sabarense CM, Dias CMGC, Lunz W, Natali AJ, Glória MBA, Peluzio MCG 2009: Fish oil ingestion reduces the number of aberrant crypt foci and adenoma in 1,2-dimethylhydrazine-induced colon cancer in rats. Braz J Med Bio Res 12: 1167-1172 
Nemcová R, Bomba A, Gancarčíková S, Herich R, Guba P 1999: Study of the effect of Lactobacillus paracasei and fructooligosacharides on the faecal microflora in weanling piglets. Ber Mun Tier Woch 7: 225-228

Rafter J 2004: The effects of probiotics on colon cancer development. Nutr Res Rev 17: 277-284

World Health Statistics 2008: WHO Press, May 110 p. 